ZOOLOGIA 28 (3): 291-296, June, 2011

doi: $10.1590 /$ S1984-46702011000300002

\title{
Coordinated feeding tactics of the Guiana dolphin, Sotalia guianensis (Cetacea: Delphinidae), in Ilha Grande Bay, Rio de Janeiro, Brazil
}

\author{
Rodrigo H. O. Tardin¹, Mariana A. Especie'; Mariana F. Nery'; \\ Felipe T. D'Azeredo' \& Sheila M. Simão'
}

${ }^{1}$ Laboratório de Bioacústica e Ecologia de Cetáceos, Departamento de Ciências Ambientais, Universidade Federal Rural do Rio de Janeiro, Rodovia BR 465, km 7, 23890-000 Seropédica, Rio de Janeiro, Brazil.

${ }^{2}$ Corresponding author: E-mail: rhtardin@gmail.com

\begin{abstract}
Differences in distribution, prey species, season and social learning opportunities influence the feeding tactics used by marine mammals. Here, we analyze the coordinated feeding behavior of the Guiana dolphin, Sotalia guianensis (Van Bénéden, 1864, Delphinidae) and its relation to seasonality and the presence of calves. In a total of 201 feeding bouts, we observed four types of coordinated feeding tactics, which differed in frequency and in mean number of engaged individuals. Tactics in which dolphins used their bodies to herd and capture prey were the most frequent, presenting a higher frequency and engaging a higher number of individuals, suggesting that these tactics are better for capturing fishes which form larger schools. Furthermore, the seasons influenced the feeding behavior used by dolphins. During springsummer, a longer duration of bouts and a larger number of individuals engaged in the feeding tactics was observed, which may be related to the seasonal spawning of larger schooling fish, such as Sardinella brasiliensis (Steindachner, 1879). Calves were present in $95 \%$ of all coordinated feeding tactic occurrences. This study indicates a complete preference of dolphins for coordinating their actions to capture prey and for the first time reports the presence of calves in the coordinated tactics and jumps. This broadens the current knowledge of the Guiana dolphin feeding tactics.
\end{abstract}

KEY WORDS. Behavioral flexibility; feeding repertoire; social foraging; social learning.

Due to their size, energetic needs and great mobility, large endothermic predators may influence their prey populations (TERBORGH 1990). In response, prey have developed antipredator strategies, forcing predators to enhance their hunting repertoire (Krebs \& Davies 1992). Coordinated hunting has been reported in several mammals (PACKER \& RUTTAN 1988) and even in one bird species (e.g. BEDNARZ 1988). Differences in distribution, prey species, seasons, and social learning opportunities may influence the feeding tactics used by marine mammals (RENDELL $\&$ Whitehead 2001). Coordinated feeding may be very important for dolphins which work together, since this enables them to establish and reinforce social bonds (WÜrSIG 1986).

The Guiana dolphin, Sotalia guianensis (Van Bénéden, 1864), is a small delphinid which can be found from northern Honduras to southern Brazil, inhabiting estuaries and bays (SimÕes-Lopes 1998, CarR \& BONDE 2000). The diet of Guiana dolphins has been investigated in detail along the Brazilian coast, demonstrating an opportunistic and generalistic feeding habit in which their main prey tends to form small or large schools with pelagic or demersal habits (Di BeneditTo \& Ramos 2004). Among them, fish which tend to form large schools, such as Sardinella brasiliensis (Steindachner, 1879), Trichiurus lepturus (Linnaeus, 1758) and Harrengula clupeola (Cuvier, 1829) and smaller schools such as Micropogonias furnieri (Quoy \& Gaimard, 1825) are reported to inhabit the Ilha Grande bay waters (R. Bernardes, Universidade de São Paulo, unpubl. data). Little is known about the individual tactics used by $S$. guianensis to capture prey, as well as the mean number of individuals engaged and the participation of calves (Rossi-SANTOS \& Flores 2009). Coordinated feeding behavior data is more detailed in other delphinid species in different habitats (e.g. WüRsIG 1986, Bel'́ovich et al. 1991, Neumann \& Orams 2003).

Given its "data deficient" status by IUCN (2004), the objectives of this study were two. First, to investigate the tactics that dolphins use to capture prey, along with the number of individuals engaged in each tactic. The hypothesis tested was that some tactics would present higher frequency of occurrence and engage a higher number of individuals than others, since feeding tactics may be linked to prey schooling patterns. Therefore, different tactics could be used to capture fishes which form different school sizes and the number of dolphins engaged in each tactic would be a reflection of fish school size. The prediction associated with this hypothesis is that feeding tactics in which dolphins use themselves as a barrier to herd and capture prey will engage a higher number of individuals, since we believe that this type of coordination may 
more effectively trap larger fish schools. BeL'колітсн et al. (1991) suggest that the success of a feeding tactic will depend on the ability of the dolphin to restrict prey activity and maneuverability. The second objective was to verify if the feeding behavior duration and the number of individuals engaged varied during the seasons. The second hypothesis is that during some periods of the year, dolphins would spend more time feeding and would aggregate a higher number of individuals in the feeding tactic than during others. This hypothesis derives from Matsuura (1978) and Vasconcellos et al. (in press) who report that fish communities which are known to be part of the $S$. guianensis diet have seasonal spawning and abundance. The predictions associated with this hypothesis are that dolphins will spend a higher amount of time, and engage a higher number of individuals, in their feeding behavior during spring and summer, since large schools of $S$. brasiliensis and $H$. clupeola spawn during these seasons, influenced by the South Atlantic Central Waters (SACW). The presence of calves during the feeding behavior, as a proxy to infer the importance of this area as a nursing and learning ground, was also quantified.

\section{MATERIAL AND METHODS}

The Ilha Grande Bay is located along the southern coast of the state of Rio de Janeiro (Fig. 1) forming together with the Sepetiba Bay, a great estuarine system (Signorini 1980). Marine habitats of the bay act as transition areas between the land and the sea (NogARA 2000) receiving organic matter from the river drainage and mangrove production. From the sea, Ilha Grande bay receives deep waters rich in nutrients derived from the South Atlantic Central Waters - SACW (Signorini 1980).

This study was conducted within the western part of the region, which includes areas of smaller depths $(<10 \mathrm{~m})$ and is preferentially used by the $S$. guianensis population (Lodi 2003). The Guiana dolphin population occurs all year long, and LoDI \& Hetzel (1998) reported that this area contains the largest aggregation of individuals ever seen for the species (groups of $c a$. 400 individuals).

Eighteen days of boat trips from May 2007 to March 2008 were accomplished, on board of a $7.5 \mathrm{~m}$ vessel. All boat trips were conducted following focal group procedures with continuous samplings using a digital handycam SONY DCR-TRV $120^{\circledR}$ (Altmann 1974). When a group of dolphins was sighted, the boat's velocity was reduced in order to keep a distance of 15 meters from the group. Only dolphin groups considered to be feeding were used for data collection. The feeding definition followed KaRCZMARSKI et al. (2000), i.e. dolphins presenting an absence of directional movements, diving frequently in asynchronous fashion. To better clarify data presentation, two sampling units used in this work were defined as: 1) Feeding Bout - Continuous and discrete period of feeding (in seconds), in which one or several feeding tactics occurred (VAUGHN et al. 2008); 2) Tactics - Number of short-duration behaviors inside each feeding bout (Altmann 1974).

Since underwater visibility of feeding bouts was not possible beyond a depth of approximately $3 \mathrm{~m}$, visible surface bouts

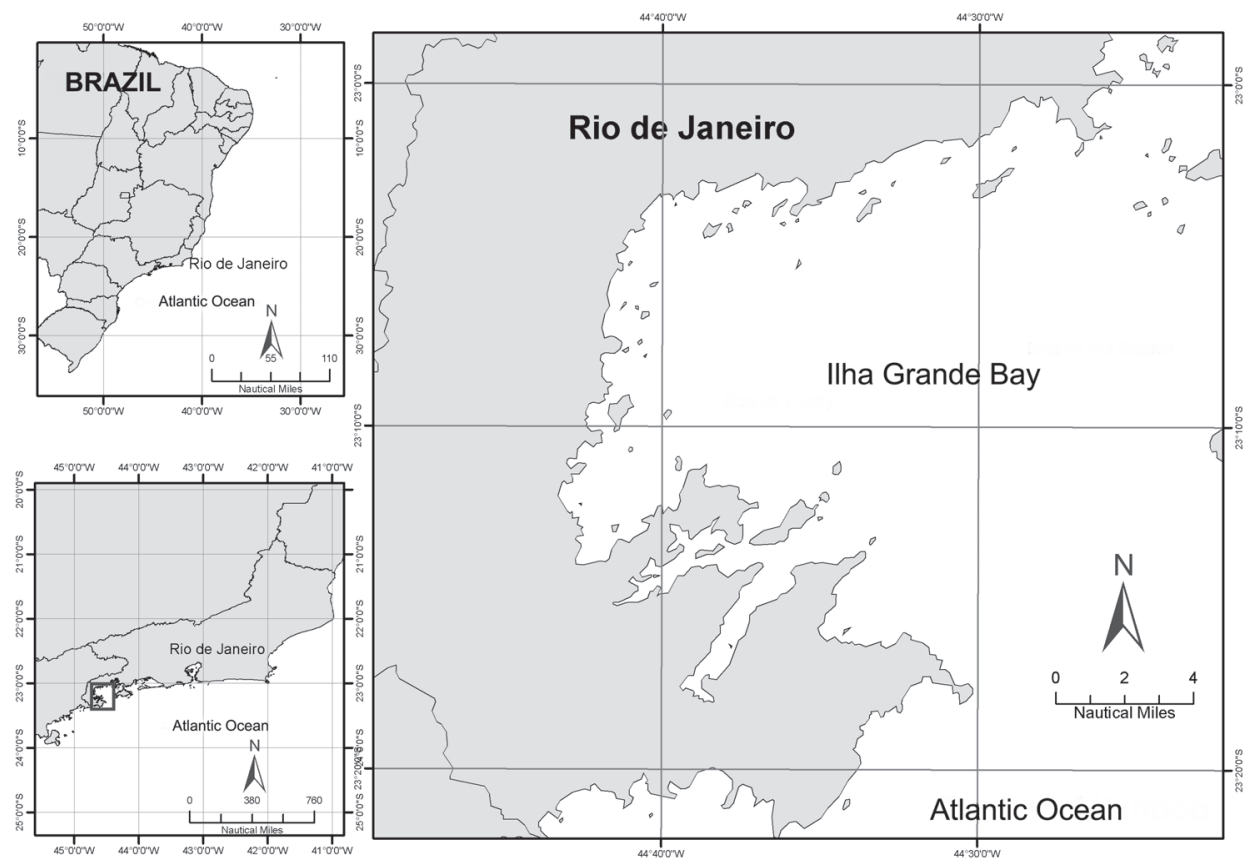

Figure 1. Map of the study area, located in Ilha Grande Bay, southeastern Brazil. 
were used as proxies for underwater activities. At the laboratory, the recorded videoclips were analyzed by two experienced observers (R.H.O Tardin \& M. A. Especie) to avoid possible errors in identifying the tactics used by dolphin groups. To reach the first objective, we quantified the occurrence frequency of tactics performed by dolphins, along with their variations, and counted the number of individuals engaged in each one. The frequency of variations was counted only within each tactic and was not compared to the whole data set. The definition of a group was the $10 \mathrm{~m}$ chain rule definition used by SMOLKER et al. (1992).

The second objective was accomplished by counting the duration of feeding bouts and the number of individuals engaged in each tactic, during all 18 days of surveys. Furthermore, if the occurrence of jumps in tactics also varied among the whole sampling period was also investigated. The presence of calves in feeding behavior was evaluated by counting the occurrence of groups containing calves in the bay, their presence on the tactics and the frequency for each one.

The Kruskal-Wallis test was used to test if the number of individuals engaged in each tactic was statistically different. To evaluate if the number of individuals engaged in variations of the main tactics was significantly different than in the main tactics, the non-parametric Mood's median test was used. This test was used since group size data may be heavily skewed and, therefore, violate the standard assumptions of the Mann Whitney U test (SEN 1998). Mood's Median test was also used to assess the statistical significance between duration of bouts and the number of individuals engaged in each tactic, within the 18 days of surveys. Finally, the chi-square test for two independent samples was used to test if the occurrence of jumps in tactics varied during the entire sampling period.

\section{RESULTS}

A total of 28.5 hours were spent on direct observation. Overall, 1,520 groups, in which no solitary individual was spotted, were observed. Therefore, all feeding activities occurred in groups. From a total of 201 feeding bouts, four types of coordinated feeding tactics were observed (Tab. I).

\section{Coordinated Feeding Tactics}

The Wall formation tactic presented two variations: Wall formation with jumps and Side-by-side Wall formation. Mood's median test showed a significant difference between the number of individuals engaged in the Wall formation with jumps compared to the main "Wall formation" tactic $\left(\chi^{2}=14.91, \mathrm{df}=1\right.$, $\mathrm{p}<0.001)$

The Perpendicular feeding tactic also presented two variations: Perpendicular feeding with jumps and Side-by-side Perpendicular feeding. Mood's Median Test showed a significant difference between the number of individuals engaged in the Perpendicular feeding with jumps compared to the main "Perpendicular feeding" tactic $\left(\chi^{2}=53.76, \mathrm{df}=1, \mathrm{p}<0.00001\right)$.

Bout mean duration was $67.8 \mathrm{~s}(60 \pm 114)$, ranging from 7.8 s to $1,266 \mathrm{~s}$. Kruskal-Wallis test showed significant differences between the number of individuals engaged and the tactics ( $\mathrm{n}=914, \mathrm{H}=121.1, \mathrm{df}=3, \mathrm{p}=0.0001$ ) (Fig. 2).

Table I. Summary of the coordinated feeding tactics of Guiana dolphins in Ilha Grande Bay, Rio de Janeiro. $\mathrm{N}=$ number of occurrences; Mean and SD data refers to number of individuals engaged in each tactic.

\begin{tabular}{|c|c|c|c|c|}
\hline Coordinated Feeding Tactic & $\mathrm{N}$ & $\%$ & $\begin{array}{l}\text { Range of the number } \\
\text { individuals engaged } \\
\text { (Mean } \pm \text { SD) }\end{array}$ & Description \\
\hline Wall formation & 375 & 48.40 & $2-200(15.2 \pm 15.5)$ & $\begin{array}{l}\text { A group of dolphins split into two subgroups which } \\
\text { join in opposite directions (BєL'KOVICH et al. 1991). }\end{array}$ \\
\hline Wall formation with jumps & 55 & 14.67 & $3-25(9.2 \pm 4.4)$ & $\begin{array}{l}\text { One or both subgroups jump before or after } \\
\text { performing the Wall formation tactic. }\end{array}$ \\
\hline Side-by-side Wall formation & 5 & 1.16 & $6-12(10.8 \pm 4.5)$ & $\begin{array}{l}\text { One or both subgroups get side-by-side before } \\
\text { performing the Wall formation tactic. }\end{array}$ \\
\hline Perpendicular feeding & 262 & 33.80 & $4-50(12.8 \pm 6.8)$ & $\begin{array}{l}\text { A group of dolphins split into two subgroups which } \\
\text { join in perpendicular directions. }\end{array}$ \\
\hline Perpendicular feeding with jumps & 84 & 32.06 & $3-17(7.9 \pm 2.6)$ & $\begin{array}{l}\text { One or both subgroups jump before or after } \\
\text { performing the Perpendicular feeding tactic. }\end{array}$ \\
\hline Side-by-side Perpendicular feeding & 27 & 8.09 & $4-30(12.7 \pm 5.8)$ & $\begin{array}{l}\text { One or both subgroups get side-by-side before } \\
\text { performing the Perpendicular feeding tactic. }\end{array}$ \\
\hline Kettle & 80 & 10.30 & $2-13(6.3 \pm 2.4)$ & $\begin{array}{l}\text { Animals dive under a school of fish, forcing it to the } \\
\text { surface, emerging from several directions } \\
\text { (BEL'KOVITCH et al. 1991). }\end{array}$ \\
\hline Line abreast & 58 & 7.50 & $4-15(7.7 \pm 2.9)$ & $\begin{array}{l}\text { Animals form a tight line, swimming side-by-side, } \\
\text { separated by no more than one dolphin-body } \\
\text { width (NEUMANN \& ORAMS 2003). }\end{array}$ \\
\hline
\end{tabular}




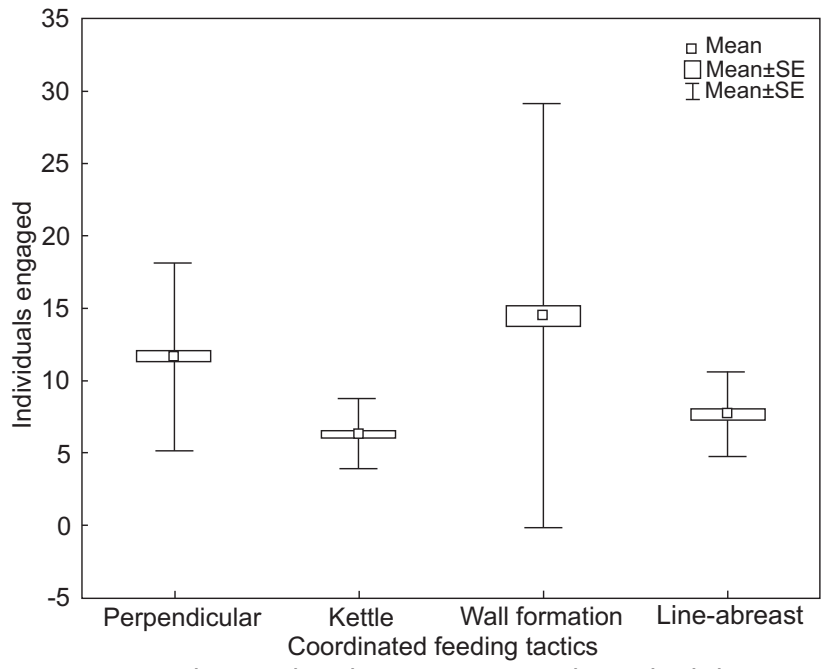

Figure 2. Boxplot graphic showing mean and standard deviation of the number of individuals engaged for each coordinated feeding tactics.

\section{Seasonal Variations}

Mood's median test showed that two distinct sampling periods, within the 18 days of survey, were statistically different $\left(\chi^{2}=19.12, \mathrm{df}=1, \mathrm{p}<0.0001\right)$. In the spring-summer period, bouts were longer $\left(\bar{x}_{\text {spring-summer }}=165 \mathrm{~s} \pm 223\right)$ than during the autumn-winter period $\left(\overline{\mathrm{x}}_{\text {autumn-winter }}=43.8 \mathrm{~s} \pm 0.86\right)$. There were also differences between the number of individuals engaged in the tactics and among these two periods (Tab. II) (Wall formation: $\chi^{2}=148.68, \mathrm{df}=1, \mathrm{p}<0.0001$; Perpendicular feeding: $\chi^{2}=57.84, \mathrm{df}=1, \mathrm{p}<0.0001$; Kettle: $\chi^{2}=4.84$, df $=1$, $\mathrm{p}<0.028$; Line abreast: $\chi^{2}=4.58, \mathrm{df}=1, \mathrm{p}<0.032$ ). Of 139 jump occurrences in the coordinated feeding tactics, $81.3 \%$ $(\mathrm{n}=113)$ was observed in the autumn-winter, while $18.7 \%$ in the spring-summer period. The chi-square test showed significant differences between them $\left(\chi^{2}=51.26, \mathrm{df}=1, \mathrm{p}=0.00001\right)$.

Table II. Number of individuals engaged in each tactic during the two sampling periods. $\mathrm{N}=$ number of occurrences; Mean and SD data refers to number of individuals engaged in each tactic.

\begin{tabular}{lrcrrrr}
\hline \multirow{2}{*}{$\begin{array}{c}\text { Coordinated } \\
\text { feeding tactic }\end{array}$} & \multicolumn{2}{c}{ Autumn-Winter } & & \multicolumn{2}{c}{ Spring-Summer } \\
\cline { 2 - 3 } \cline { 6 - 7 } & $\mathrm{N}$ & Mean \pm SD & & $\mathrm{N}$ & Mean \pm SD \\
\hline Wall formation & 181 & $8.9 \pm 4.2$ & & 194 & $21.1 \pm 19.3$ \\
Perpendicular feeding & 124 & $9.7 \pm 3.7$ & & 138 & $15.7 \pm$ & 7.7 \\
Kettle & 46 & $5.6 \pm 1.9$ & & 34 & $7.2 \pm 2.8$ \\
Line abreast & 34 & $6.9 \pm 2.5$ & & 24 & $8.7 \pm$ & 3.1 \\
\hline
\end{tabular}

\section{Calves and Feeding Tactics}

From a total of 1,327 sighted groups, $86.1 \%(\mathrm{n}=1,357)$

had calves as their members. Calves were present in $95 \%$ of the
953 coordinated feeding tactic occurrences, being more frequently seen in the Wall formation $(38.2 \% ; \mathrm{n}=350)$ and less in the Line abreast formation $(6.0 \% ; \mathrm{n}=55)$.

\section{DISCUSSION}

As in dolphins, coordinated feeding tactics frequently occur in several terrestrial predator species [e.g. lions, Panthera leo (Linnaeus, 1758), (Schaller 1972); chimpanzees, Pan troglodytes (Blumenbach, 1799) (Goodall 1990); and African wild dogs, Lycaon pictus (Temminck, 1820), (Creel \& Creel 1995)]. To overcome antipredator methods, predators of schooling fish develop their own tactics (MAJOR 1978). For Delphinidae, this selective pressure enabled a great diversity of feeding strategies, indicating a higher level of behavioral plasticity (WüRSIG 1986).

This work presents data that indicates a complete preference of coordination in order to capture prey. The high frequency of occurrence observed in the Wall formation suggests a higher individual energy intake. Moreover, this tactic appears to overcome prey defenses by using the confusion effect against the prey themselves, through attack from multiple locations, rendering prey incapable of polarization (Роттs 1983). Interestingly, previous studies with bottlenose dolphins, Tursiops truncatus (Montagu, 1821) and common dolphins, Delphinus delphis (Linnaeus, 1758) (BeL'коvitch et al. 1991, Neumann \& Orams 2003, respectively) report the same tactics observed here, suggesting a possible convergent evolution regarding feeding tactics, in order to adapt to similar selective pressures from different habitats.

BeL'Kovitch et al. (1991), working with T. truncatus, reports a high frequency of the Wall formation in the western Crimea region, Russia. However, Neumann \& Orams (2003) studying the bottlenose dolphin in deeper regions such as New Zealand, found that Kettle is the most observed tactic, suggesting that depth might be correlated with its occurrence.

To date, no published work with Guiana dolphins quantifies the presence of jumps during the coordinated feeding behavior. ACEVEDo-GutierREz (1999) suggests that, for bottlenose dolphins, jumping would have a fish driving function, thus enhancing the capture of prey. Under these circumstances, jumps would be acting as a facilitating agent, possibly helping to push prey against a dolphin barrier, which seems to be the case here.

However, other explanations are provided to the association of jumps in the coordinated feeding behavior. NoRRIS \& DoHL (1980) suggest a social facilitation function to the jumps, where dolphins would use it to aggregate, reaffirming social bonds, while LuSSEAU (2006) suggests a non-verbal type of communication, which would avoid competition between the groups. Despite the communicative meaning, which wasn't our objective, the higher occurrence of jumps associated to the coordinated feeding tactics suggests its use to enhance prey capture success. 
The number of individuals engaged in the tactics was highly differentiated. A higher number of individuals engaged in the Wall formation and Perpendicular feeding may suggest that these tactics are better to herd larger schools of prey, such as $S$. brasiliensis and H. clupeola. The use of jumps by groups of few individuals herding prey (Tab. I) suggests that body impact on the water was efficient in tightening schools of prey despite the small number of feeding dolphins. This would increase their capture success and still be advantageous, since these groups may not share the same benefits of larger groups.

A larger duration of bouts and a higher number of individuals engaged in feeding tactics during the spring-summer period suggest that the temporal dynamics of prey, such as $H$. clupeola and $S$. brasiliensis which tend to form large schools and spawn in these seasons (VAsConcellos et al. in press), appear to influence the coordinated feeding behavior of Guiana Dolphins. Similarly, prey such as the Whitemouth Croaker ( $M$. furnieri), which form small schools of fish and spawn mainly during autumn and winter (Haimovici \& Ignacio 2005), possibly suggests that the smaller bout duration and number of individuals feeding observed in these periods may be a reflex of S. guianensis prey schooling patterns. In fact, Social foraging theory suggests that animals should maximize individual intake, thus aggregate to exploit available food resources (Giraldeau \& Caraco 2000).

The large presence of calves in coordinated feeding tactics may suggest that this behavior would be a potential candidate for social learning in dolphins, especially between the mother and her calf, as reported by Bender et al. (2008) in Atlantic spotted dolphins, Stenella frontalis (Cuvier, 1829). Therefore, the shallow and protected waters of Ilha Grande bay may be an opportunistic site for social learning in S. guianensis.

Most studies regarding coordinated feeding tactics do not quantify the number of individuals engaged, the presence of calves nor the associated events, such as jumps (e.g. BeL' КоVICH et al. 1991, Neumann \& Orams 2003, Rossi-Santos \& Flores 2009). Therefore, this paper provides more details of the coordinated feeding tactics of dolphins, by quantifying the presence of calves and associated events in feeding tactics, especially for the poorly known Guiana dolphins.

\section{ACKNOWLEDGMENTS}

We sincerely thank Sergio C. Moreira from the Instituto Aqualie, Lauren Stanton for English language services, Bill Rossiter for the financial support provided by the Cetacean Society International (CSI) and two anonymous reviewers who made helpful comments to improve the language and the presentation of the manuscript. We also thank, Dona Elsa, Gilberto and Tico for their services and many trainee students from the Laboratório de Bioacústica e Ecologia de Cetáceos, Universidade Federal Rural do Rio de Janeiro (UFRRJ). Rodrigo H.O. Tardin is part of the Programa de Pós Graduação em Ecoogia e Evolução,
Universidade do Estado do Rio de Janeiro and Mariana A. Espécie is part of the Programa de Pós-Graduação em Biologia Animal, UFRRJ. Mariana F. Nery is also part of the Instituto de Ecología y Evolución, Valdívia, Chile. Personnel for this study were partially supported by the Fundação de Amparo à Pesquisa do Estado do Rio de Janeiro (FAPERJ) (R.H.O. Tardin, Grant number E-26/151.047/2007); the Conselho Nacional de Pesquisa e Desenvolvimento (CNPq) (M.A.Espécie, Grant Number 111555/ 2008-6), and the Coordenação de Aperfeiçoamento de Pessoal de Nível Superior (CAPES) (R.H.O. Tardin, and M.A.Espécie).

\section{LITERATURE CITED}

Acevedo-Gutierrez, A. 1999. Aerial behavior is not a social facilitator in bottlenose dolphins hunting in small groups. Journal of Mammalogy 80 (3): 768-776.

Altmann, J. 1974. Observational study of behavior: Sampling methods. Behavior 49 (3-4): 227-267.

Bednarz, J.C. 1988. Cooperative hunting in Harris' hawks (Parabuteo unicinctus). Science 239 (4847): 1525-1527.

Bel'kovich, V.M.; E.E. Ivanova; O.V. Yefremenkova; L.B. Kozarovitsky \& S.P. Kharitonov. 1991. Searching and hunting behavior in the bottlenose dolphin (Tursiops truncatus) in the Black Sea, p. 38-67. In: K. Pryor \& K.S. Norris (Eds). Dolphin Societies: Discoveries and Puzzles. Berkeley, University of California Press, 397p.

Bender, C.E.; D.L. Herzing \& D.F. Bjorklund. 2008. Evidence of teaching in Atlantic spotted dolphins by mother dolphins foraging in the presence of their calves. Animal Cognition 12 (1): 43-53.

CARR, T. \& R.K. BONDE. 2000. Tucuxi (Sotalia fluviatilis) occurs in Nicaragua, $800 \mathrm{~km}$ north of its previously known range. Marine Mammal Science 16 (2): 447-452.

Creel, S. \& N.M. Creel. 1995. Communal hunting and pack size in African wild dogs, Lycaon pictus. Animal Behaviour 50 (5): 1325-1339.

Di Beneditto, A.P.M. \& R.M.A. Ramos. 2004. Biology of the marine tucuxi dolphin (Sotalia fluviatilis) in south-eastern Brazil. Journal of the Marine Biological Association of the United Kingdom 84 (6): 1245-1250.

Giraldeau, L.A. \& T. Caraco. 2000. Social foraging theory. Princeton, Princeton University Press, 376p.

Goodall, J. 1990. Through a window: my 30 years with the chimpanzees of Gombe. Boston, Houghton Mifflin Company, 400p.

Haimovici, M \& J.M. Ignacio. 2005. Micropogonias Furnieri, p. 101-107. In: C.L.W. Rossi; M.C. Cergolle \& A.O. Ávila-DA-SiLVA (Eds). Análise das principais pescarias comerciais da região sudeste-sul do Brasil: Dinâmica populacional das espécies em exploração. São Paulo, Instituto Oceanográfico. IUCN 2004. Red List of Threatened Species. Gland, IUCN, 217p.

Karczmarski, L.; V.C. Cockcroft \& A. Mclachlan. 2000. Habitat use and preferences of Indo-Pacific humpback dolphins 
Sousa chinensis in Algoa Bay, South Africa. Marine Mammal Science 16 (1): 65-79.

Krebs, J.R. \& N.B. Davies. 1992. Behavioral ecology: an evolutionary approach. Sunderland, Sinauer Associates, 464p.

LoDI, L. 2003. Seleção e uso do hábitat pelo boto-cinza, Sotalia guianensis (van Béneden, 1864) (Cetacea: Delphinidae), na Baía de Paraty, Estado do Rio de Janeiro. Bioikos 17 (1-2): 5-20.

Lodi, L. \& B. Hetzel. 1998. Grandes agregações do boto-cinza (Sotalia fluviatilis) na Baía da Ilha Grande, Rio de Janeiro. Bioikos 12 (2): 26-30.

Lusseau, D. 2006. Why do dolphins jump? Interpreting the behavioural repertoire of bottlenose dolphins (Tursiops sp.) in Doubtful Sound, New Zealand. Behavioral Processes 73 (3): 257-265.

Major, P.F. 1978. Predator-prey interactions in two schooling fishes, Caranx ignobilis and Stolephorus purpureus. Animal Behaviour 26 (3): 760-777.

MatsuUra, Y. 1978. Exploração e avaliação de estoque de peixes pelágicos no sul do Brasil - Projeto integrado para o uso e exploração racional do ambiente marinho. São Paulo, Relatório Técnico do Instituto Oceanográfico, 46p.

Neumann, D.R. \& M.B. Orams. 2003. Feeding behaviours of shortbeaked common dolphins, Delphinus delphis, in New Zealand. Aquatic Mammals 29 (1): 137-149.

Nogara, P.J. 2000. Caracterização dos ambientes marinhos da Área de Proteção Ambiental de Cairuçu - Município de Paraty - RJ. Rio de Janeiro, Technical report, Fundação SOS Mata Atlântica, 83p.

NoRRIS, K.S. \& T.P. DoHL. 1980. Behavior of the Hawaiian Spinner Dolphin S. longirostris. Fishery Bulletin 77 (4): 821-849.

PACKER, C. \& L. RutTAN. 1988. Evolution of cooperative hunting. American Naturalist 132 (2): 159-198.

PotTs, G.W. 1983. The predatory tactics of Caranx melampygus and the response of its prey, p. 181-191 In: D.L.G. NOAKEs; D.G. Lindquist; G.S. Helfman \& J.A. Ward (Eds). Predators and prey in fishes. The Hague, Dr. W Junk Publishers, 230p.
Rendell, L. \& H. Whitehead. 2001. Culture in whales and dolphins. Behavioral Brain Science 24 (2): 309-382.

Rossi-Santos, M.R. \& P.A.C. Flores. 2009. Feeding strategies of the Guiana dolphins Sotalia guianensis. The Open Marine Biology Journal 3 (7): 70-76.

SCHALler, G. 1972. The Serengeti Lion. Chicago, University of Chicago Press.

SEN, P.K. 1998. Multivariate median and rank sum tests, p. 28872900. In: P. ARmitage \& T. Colton (Eds). Encyclopedia of biostatistics. Chichester, J. Wiley, 504p.

SignoRINI, S.R. 1980. A study of the circulation in bay of Ilha Grande and bay of Sepetiba. Part I, an assessment to the tidally and wind-driven circulation using a finite element numerical model. Boletim do Instituto Oceanográfico 29 (1): 41-55.

SIMÕES-Lopes, P. C. 1998. Ocorrência de uma população de Sotalia fluviatilis Gervais, 1853, (Cetacea: Delphinidae) no Limite Sul da sua distribuição, Santa Catarina, Brasil. Biotemas 1 (1): 57-62.

Smolker, R.A.; A.F. Richards; R.C. Connor \& J.W. Pepper. 1992. Sex differences in patterns of association among Indian Ocean bottlenose dolphins. Behavior 123 (1-2): 38-69.

Terborgh, J. 1990. The role of felid predators in neotropical forests. Vida Silvestre Neotropical 2 (2): 3-5.

Vasconcelllos, R.M.; F.G. Araújo; J.N.S. Santos \& M.A.Silva. (in press). Diel seasonality in fish biodiversity in a sandy beach in southeastern Brazil. Journal of Marine Biological Association of the United Kingdom. doi:10.1017/ S0025315410000652

VAUGHN, R.L.; B. WÜrsig; D.S. Shelton; L.L. Timm; L.A, WATSON. 2008. Dusky dolphins influence prey accessibility for seabirds in Admiralty Bay, New Zealand. Journal of Mammalogy 89 (4): 1051-1058.

WÜRsIG, B. 1986. Delphinid foraging strategies, p. 347-359. In: R.J. SCHUSTERman (Ed.). Dolphin cognitive and behavior: A comparative approach. Hillsdale, Lawrence Erlbaum Associates, 408p.

Submitted: 04.V.2010; Accepted: 28.I.2011.

Editorial responsibility: Lorenzo R.S. Zanette

ZOOLOGIA 28 (3): 291-296, June, 2011 